\title{
Management of athlete achievement development, central java student sports coaching and training center
}

\author{
Nunuk Indah Winarni ${ }^{1}$, Sugiharto ${ }^{2}$, Andre Yogaswara ${ }^{3^{*}}$. \\ ${ }^{1}$ SMP Negeri 2 Mranggen Kab Demak, Jl. Raya Kangkung - Sumberrejo Km. 03, Mranggen, Kabupaten \\ Demak, Jawa Tengah, Indonesia. \\ ${ }^{2}$ Ilmu Keolahragaan, Fakultas Ilmu Keolahragaan, Universitas Negeri Semarang, Sekaran, Gunungpati, \\ Kota Semarang, Jawa Tengah, Indonesia. \\ ${ }^{3}$ Ilmu Keolahragaan, Fakultas Ilmu Keolahragaan, Universitas Negeri Yogyakarta, J1. Colombo No. 1, \\ Karangmalang, Depok, Sleman, Daerah Istimewa Yogyakarta, Indonesia. \\ Corresponding Author: andreyogaswara.2020@student.uny.ac.id
}

\begin{abstract}
One of the ways that the government restricts the development of regional elite sports is to seek to establish a variety of athlete development facilities. The purpose of this study is to determine and describe the implementation of performance development management for athletes in the Central Java Student Sports Development and Training Center (PPLOP). The research method uses explanatory research techniques. The research was conducted at the Central Java Student Physical Education and Training Center (BPPLOP). Research data sources are individuals directly related to PPLOP, including PPLOP athletes, athletes and other related party managers, coaches, and performance development coordinators. Techniques for collecting data through observations, interviews and documents. The results show that the performance management of PPLOP athletes in Central Java has achieved the best results in performance development, education, academic development and religious development. The process of improving PPLOP Central Java performance is correct, as evidenced by the performance of athletes in sports, science, and religion. The existence of the promotion and dismantling system has become a reference for the school and the PPLOP Center in Central Java to implement performance promotion management.
\end{abstract}

Keywords: management, achievement coaching, PPLOP

\section{Manajemen pembinaan prestasi atlet pemusatan pembinaan dan latihan olahraga pelajar Jawa Tengah}

\begin{abstract}
Abstrak
Salah satu cara pemerintah dalam mengkondisikan pembinaan cabang olahraga unggulan di daerah adalah dengan mengupayakan berdirinya beberapa institusi pembinaan atlet. Penelitian ini bertujuan untuk mengetahui dan mendeskripsikan implementasi manajemen pengembangan kinerja atlet di Pusat Pembinaan dan Latihan Olahraga Pelajar (PPLOP) Jawa Tengah. Metode penelitian menggunakan teknik explanatory research. Penelitian ini dilakukan di Balai Pemusatan Pendidikan dan Latihan Olahraga Pelajar (BPPLOP) Jawa Tengah. Sumber data penelitian adalah individu yang berhubungan langsung dengan PPLOP, antara lain pengurus, pelatih, koordinator pengembangan kinerja atlet PPLOP, atlet dan pihak terkait lainnya. Teknik pengumpulan data melalui observasi, wawancara, dan dokumen. Hasil penelitian menujukkan bahwa penerapan manajemen kinerja atlet PPLOP di Jawa Tengah mendapatkan prestasi terbaik dalam pengembangan kinerja, pendidikan, pengembangan akademik, dan pengembangan keagamaan. Proses peningkatan prestasi PPLOP Jawa Tengah sudah baik dan benar, terbukti dari prestasi para atlet di bidang olahraga, sains dan agama. Adanya sistem promosi dan degradasi menjadi acuan bagi pelaksanaan manajemen pembinaan prestasi di sekolah maupun di lingkungan Balai PPLOP Jawa Tengah.
\end{abstract}

Kata kunci : manajemen, pembinaan prestasi, PPLOP. 


\section{PENDAHULUAN}

Olahraga merupakan kriteria minimal mengenai berbagai aspek yang berhubungan dengan gedung dan lingkungan sekitar gedung yang digunakan untuk kegiatan olahraga dan/atau penyelenggaraan kegiatan keolahragaan (Pambudi, 2020). Olahraga digunakan sebagai media untuk membuktikan bahwa sesorang dapat menemukan bakat dan keterampilannya dalam kompetisi dan menjadi pribadi yang nyata. Keberhasilan atlet dalam aktualisasi diri tercermin dari performanya (Wijayanti et al., 2016). Untuk mencapai hasil, kita perlu merumuskan rencana untuk mengendalikan dan mengembangkan hasil secara sistematis, bertahap dan berkelanjutan. (Indonesia, 2005) Undang-Undang 3 dari Sistem Keolahragaan Nasional 2005 Pasal 25(6), "dukungan ilmu pengetahuan dan teknologi keolahragaan, melalui proses pembinaan dan pengembangan yang terencana, berjenjang, dan berkesinambungan dalam rangka keberhasilan penyelenggaraan olahraga". Pasal 11 (1) Peraturan Pemerintah Nomor 16 Tahun 2007 tentang Penyelenggaraan Keolahragaan menetapkan bahwa pemerintah provinsi berhak mengatur, membina, mengembangkan, melaksanakan, dan mengawasi penyelenggaraan keolahragaan. Salah satunya adalah Pusat Pembinaan dan Latihan Pelajar (PPLP). Mendirikan banyak PPLP untuk semua cabang olahraga jelas tidak mungkin karena tidak akan fokus dan tidak efisien sehingga akan membebani pada aspek pengelolaan dan maintenance. Oleh sebab itu PPLP difokuskan pada cabang olahraga tertentu sesuai potensi pelajar dan kemampuan daerah dalam pengelolaannya.

Pelajar sebagai subyek utama untuk dijadikan cikal bakal atlet berprestasi dimasa mendatang, hal ini dikarenakan jumlah pelajar yang sangat banyak sehingga memiliki peluang besar untuk dimunculkannya atlet-atlet yang berpotensial jika mendapat pembinaan secara baik, benar dan berkesinambungan (Kristiyanto, 2016). Sebagai kelanjutan dari pembinaan dan pelatihan olahraga pelajar di Jawa Tengah, maka didirikanlah Balai Pemusatan Pendidikan dan Latihan Olahraga Pelajar (BPPLOP). Perannya adalah untuk menarik atlet masa depan, meningkatkan keterampilan siswa atlet, dan mempromosikan olahraga mahasiswa di Jawa Tengah (DINPORAPAR, 2018). Pemusatan Pendidikan dan Latihan Olahraga Pelajar (PPLOP) merupakan bagian dari sistem pengembangan kinerja yang komprehensif bagi para atlet. Dengan menggabungkan pengembangan prestasi dengan sekolah formal, memiliki nilai strategis dan manfaat dari mengembangkan dan memajukan prestasi Indonesia. Secara teori, usia atlet PPLOP adalah kedua dalam piramida pembinaan olahraga.

Pelaksanaan PPLOP tidak terlepas dari manajemen yang berada di dalamnya, karena dengan adanya pengelolaan manejemen yang baik maka dapat tercipta pembinaan atlet yang optimal. Yuniana \& Nasrulloh, (2019) menyatakan bahwa pentingnya pengelolaan manajemen terhadap keberhasilan organisasi. Karyoto (2016:4) menyatakan, manajemen berasal dari kata manage to man, yang jika digabungkan maka berarti mengelola atau mengatur manusia. Perlu dilakukan upaya-upaya untuk mendorong organisasi ke depan agar dapat beroperasi dengan tertib dan tertib, tentunya membutuhkan seseorang yang dapat sangat berdedikasi dan bertanggung jawab dalam merencanakan, mengorganisir, menggerakkan dan memantau kegiatan (Harsuki, 2013). Manajemen adalah kegiatan yang dilakukan guna mewujudkan tujuan yang harus dicapai organisasi. Agar manajemen organisasi berjalan dengan baik harus memperhaikan fungsi manajemen, (Nasrulloh et al., 2020). Implementasi fungsi manajemen berupa planning, organizing, staffing, directing, and controlling juga penting bagi organisasi, (Nasrulloh et al., 2021). (1) Perencanaan merupakan kegiatan yang dilakukan pada saat ini untuk menentukan masa depan (Karyoto, 2016:51). Sementara itu, Terry (2012:43) mengemukakan bahwa perencanaan adalah proses memutuskan tujuan apa yang akan dikejar dalam periode waktu berikutnya dan apa yang akan dilakukan untuk mencapai tujuan tersebut.

Fungsi perencanaan adalah peramalan, penetapan tujuan, perencanaan, penjadwalan dan penganggaran (Karyoto, 2016: 54). Manfaat dari rencana tersebut adalah untuk mengurangi risiko, memperjelas arah kegiatan, melibatkan organisasi, mengurangi pemborosan dan 
menjadi dasar pengendalian (Karyoto, 2016: 56). (2) Organisasi adalah untuk kerja kelompok. Berorganisasi karena pekerjaan organisasi berbeda dengan pekerjaan individu. Terry (2012:82) menyatakan, "proses pengelompokan kegiatan untuk mencapai tujuan dan menugaskan setiap kelompok kepada seorang manajer". (3) Actuating adalah tindakan manajer organisasi untuk membuat karyawan bersemangat menyelesaikan tugas (Karyoto, 2016:99). Terry (2012:181) mengemukakan bahwa arahnya adalah mengintegrasikan upaya-upaya anggota kelompok untuk melaksanakan tugasnya, sehingga dapat mencapai tujuan kelompok atau individu dalam melaksanakan tugasnya. (4) Pengendalian adalah kegiatan yang dilakukan untuk mencegah berbagai pelanggaran kerja yang dapat menimbulkan pemborosan kerja (Karyoto, 2016:119).

\section{METODE}

Penelitian ini merupakan Basic Interpretive Research (Ary et al., 2009) menyatakan, "Penelitian ini menjelaskan, menafsirkan, mengidentifikasi, dan mendeskripsikan pelaksanaan manejemen pembinaan prestasi atlet Pemusatan Pendidikan dan Latihan Olahraga Pelajar (PPLOP) Jawa Tengah". Penelitian ini dilakukan di Balai Pemusatan Pendidikan dan Latihan Olahraga Pelajar (BPPLOP) Jawa Tengah. Sumber data dalam penelitian adalah orang-orang yang memiliki keterkaitan secara langsung di PPLOP diantaranya Pimpinan PPLOP, pembina PPLOP Jawa Tengah, koordinator bidang pembinaan prestasi atlet PPLOP, pelatih, atlet, dan pihak lain terkait.

Teknik pengumpulan data yang paling cocok adalah: observasi atau observasi, wawancara dan dokumen. Model analisis yang digunakan dalam studi pendahuluan penelitian ini adalah model analisis interaktif Miles dan Huberman. Kegiatan analisis data dilakukan secara interaktif dan berlanjut hingga selesai, meliputi reduksi data, penyajian data, dan penarikan kesimpulan (Sugiyono, 2015). Proses analisis interaktif dapat dilihat pada Gambar di bawah ini.

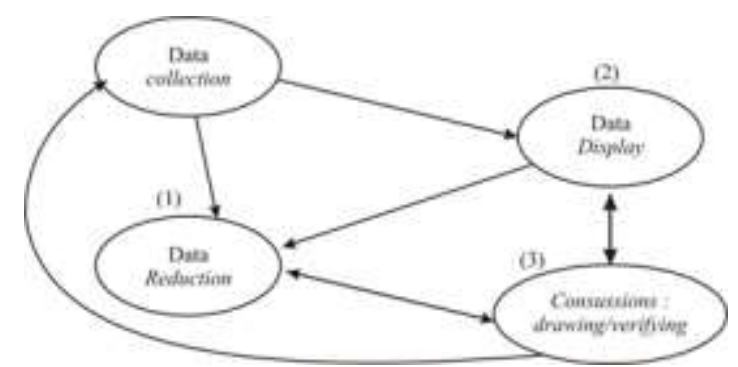

Gambar 1. Komponen dalam Analisis Data

\section{HASIL DAN PEMBAHASAN}

Olahraga pada dasarnya merupakan kebutuhan setiap manusia di dalam kehidupan, agar kondisi fisik dan kesehatannya tetap terjaga dengan baik dan salah satu cara agar kesehatan tetap terjaga dengan baik adalah melalui olahraga (Prasetyo, 2015). Olahraga adalah semua kegiatan fisik yang sengaja dan sistematis untuk mendorong, mendorong, dan mengembangkan potensi fisik, spiritual dan sosial (Adzalika et al., 2019). Olahraga secara spesifik dapat meningkatkan derajat kesehatan bagi pelakunya adalah olahraga Kesehatan Olahraga (Alim, 2019). Hari ini telah menjadi prestise suatu negara atau wilayah, di mana banyak menghabiskan biaya besar dalam pertandingan olahraga. Untuk mencapai kesuksesan begitu banyak masalah yang dihadapi (Yahya \& Irfandi, 2020). Keberadaan masalah olahraga karena munculnya kebutuhan masyarakat, yang dalam hal ini adalah atlet siswa, yang tidak puas dan tidak adanya aturan atau pedoman dalam pelaksanaan kegiatan olahraga (Allung et al., 2019). Masalah ini harus segera ditangani dengan membuat aturan atau pedoman sebagai referensi dalam mengimplementasikan implementasi olahraga. Secara sosial, olahraga dapat digunakan sebagai media sosialisasi melalui interaksi dan komunikasi dengan orang lain atau lingkungan sekitar. Salah satu indikasi meningkatnya keinginan masyarakat akan derajat kesehatan yang tinggi, 
penampilan jasmani yang proporsional dan aktualisasi diri yang lebih luas dalam lingkungannya mencerminkan bahwa kebutuhan masyarakat semakin beragam sehingga membutuhkan tempat atau wahana yang dapat menyalurkan serta memenuhi kebutuhan tersebut (Danardani, 2015).

Pencapaian prestasi olahraga, merupakan proses yang kompleks dan banyak faktor yang harus diperhatikan dan dilatih untuk mencapai prestasi yang optimal. Faktor yang mempengaruhi pencapaian prestasi tersebut diantaranya adalah antaranya kondisi fisik/ biomotor, kemampuan penguasaan teknik dan taktik, serta faktor psikologikal (Alim, 2019). Pencapaian prestasi yang optimal dipengaruhi oleh faktor fisiologi (kondisi fisik/biomotor), penguasaan gerak (teknik), nutrisi, dan psikologis atlet. Keseluruhan faktor tersebut saling mendukung satu sama lain dalam pencapaian peforma yang optimal. Keberhasilan atlet akan terlihat dalam suatu kejuaraan-kejuaran baik ditingkat Nasional ataupun Internasional. Keberhasilan tersebut juga perlu didukung akan hadirnya sebuah kebijakan keolahragaan. Kebijakan keolahragaan dibuat untuk mengatur, mengarahkan melalui pembinaan dan pengembangan potensi atlet-atlet berprestasi (Hadiyanto \& Khamidi, 2021). Perkembangan prestasi olahraga Indonesia adalah tanggung jawab kita sebagai warga negara. Komite Nasional Olahraga Indonesia (KONI) adalah wadah olahraga nasional yang menaungi olahraga di Indonesia (Hidayat et al., 2019). Menciptakan suatu prestasi dapat dilakukan melalui pembinaan yang berkesinambungan, teratur dan sistematis oleh seluruh komponen yang bersangkutan, baik itu pelatih, dan seluruh stakeholder terkait. Keberhasilan suatu pembinaan prestasi yang sistematis, lengkap, langsung dan sesuai prosedur terlihat jelas dari berbagai faktor yang mempengaruhi (Damayanti, 2019; Haryadi et al., 2017) yaitu: (a) potensi atlet (atlet berbakat) yang cukup. (b) pelatih yang profesional dalam menerapkan ilmu pengetahuan dan teknologi. (c) sarana dan prasarana olahraga yang layak dan memadai. (d) Adanya perencanaan yang berkesinambungan didukung oleh ketersediaan anggaran yang memadai dan hubungan baik antar pihak (KONI, pemerintah, atlet, pelatih, pengurus, Pengprov). (e) pengujian dan pengukuran kondisi atlet yang dilakukan secara teratur berkala.

Aswin (2017:112), pembinaan adalah proses dimana orang memperoleh keterampilan tertentu untuk membantu mencapai tujuan organisasi. Oleh karena itu, proses ini terkait dengan berbagai tujuan organisasi. (Iklil \& Khamidi, 2021)mendefinisikan pembinaan sebagai upaya untuk meningkatkan kinerja karyawan dalam pekerjaan langsung lainnya. Dikombinasikan pula dengan definisi tersebut, (Iklil \& Khamidi, 2021)mengangkat beberapa poin penting, yaitu manajemen merupakan proses sistematis yang mengubah perilaku kerja karyawan/kelompok karyawan dalam upaya meningkatkan kinerja organisasi. Pembinaan terkait dengan keterampilan dan kemampuan yang diperlukan untuk pekerjaan yang sekarang dilakukan. Pembinaan berorientasi ke masa sekarang dan membantu pegawai untuk menguasai keterampilan dan kemampuan (konpetensi) yang spesifik untuk berhasil dalam pekerjaannya (Nicolas et al., 2011)

Pembinaan dapat diartikan sebagai segala upaya dan kegiatan yang berkaitan dengan perencanaan, pengorganisasian, pembiayaan, perencanaan, koordinasi, pelaksanaan dan efektivitas, guna mencapai tujuan dengan hasil yang setinggi-tingginya (Yulisatria et al., 2021). Fungsi pembinaan adalah sebagai berikut: (a) penerapan teori. (b) melaksanakan perencanaan operasional dengan membuat rencana strategis dan taktis dengan menerima masukkan dari pihak lain. (c) tercapaianya visi, misi, tujuan dan sasaran organisasi. (d) memfasilitasi dan mempertahankan sumber yang dimiliki. (e) mempertahankan moral yang baik. (f) memberikan program pelatihan dan pendidikan. (g) menyediakan dan mempertahankan kebijakan, prosuder, peraturan dan regulasi. (h) disiplin dalam setiap kegiatan. (i) memudahkan dan mempertahankan hubungan interpersonal. (j) memberikan kesempatan untuk konseling. (k) Membangun dan mempertahankan kepercayaan dan kerja tim. (l) memanage konflik. (m) 
sumber daya manusia potensial sebagai aset organisasi dikelola dengan sebaik mungkin. (n) mendelegasikan wewenang.

Tujuan umum adanya suatu pembinaan adalah; (a) mengembangkan keahlian agar menyelesaikan pekerjaannya lebih cepat dan tepat. (b) mengembangkan pengetahuan, agar pekerjaan selesai secara rasional. (c) mengembangkan sikap dan kemauan untuk saling bekerjasama diantara para pegawai dan para pempinan. Nurjaya (2008:76) menyatakan, "Komponen suatu pembinaan terdiri dari: (a) terdapat tujuan dan sasaran pembinaan dan pengembangan yang jelas dan dapat di ukur. (b) adanya pembina yang profesional. (c) pembinaan dan pengembangan harus sesuai dengan tujuan yang hendak dicapai. (d) para pelaku harus memenuhi persyaratan yang ditentukan".

Suatu rencana pembinaan memerlukan tahapan atau langkah-langkah yang sistematis agar dapat berguna dan bermanfaat (Putra, 2018). Pembinaan secara umum dibagi menjadi tiga tahap: tahap perencanaan pelatihan, tahap pelaksanaan pelatihan dan tahap evaluasi pelatihan. Mutohir (2007:28) mengemukakan, ada dua sistem pelatihan olahraga yang dikenal, yaitu pelatihan olahraga yang menekankan pada olahraga elit dan pelatihan olahraga yang menitikberatkan pada olahraga dan budaya olahraga. Olahraga elit (physicalization of sport) ditandai dengan kompetisi dan maksimalisasi kinerja. Olahraga prestasi memerlukan model latihan yang terstruktur dan berkelanjutan. Model yang akan dilaksanakan harus memiliki rencana latihan dan kegiatan olahraga yang lengkap, teratur, dan sistematis, serta harus dipelihara sepanjang tahun tanpa henti atau henti. Rencana latihan kegiatan latihan dan olahraga untuk meningkatkan prestasi tertinggi tersebut di atas memerlukan waktu yang lama dan bertahap sesuai dengan perkembangan dan pertumbuhan fisik dan mental anak.

Mutohir (2007:5) menyatakan bahwa pembinaan dan koordinasi pembinaan terjadi di semua jalur pembinaan, termasuk olahraga prestasi, olahraga pendidikan, dan olahraga masyarakat dan hubungannya dengan semua aspek lainnya. Sistem pelatihan olahraga yang terkenal adalah sistem piramidal, dan elemen-elemen yang ada saling berhubungan dan tidak dapat dipisahkan. Jenjang pembinaaan olahraga prestasi dari sistem piramida tersebut dapat dilihat pada gambar dibawah ini

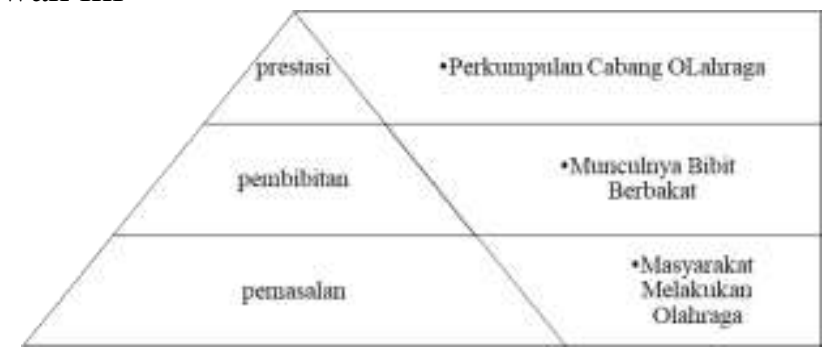

Gambar 2. Sistem Piramida Pola Pembinaan Atlet

(Kebijakan Depdikbud tentang Olahraga di Kalangan Pelajar dalam Upaya Menunjang Pembinaan, Jakarta. 1996)

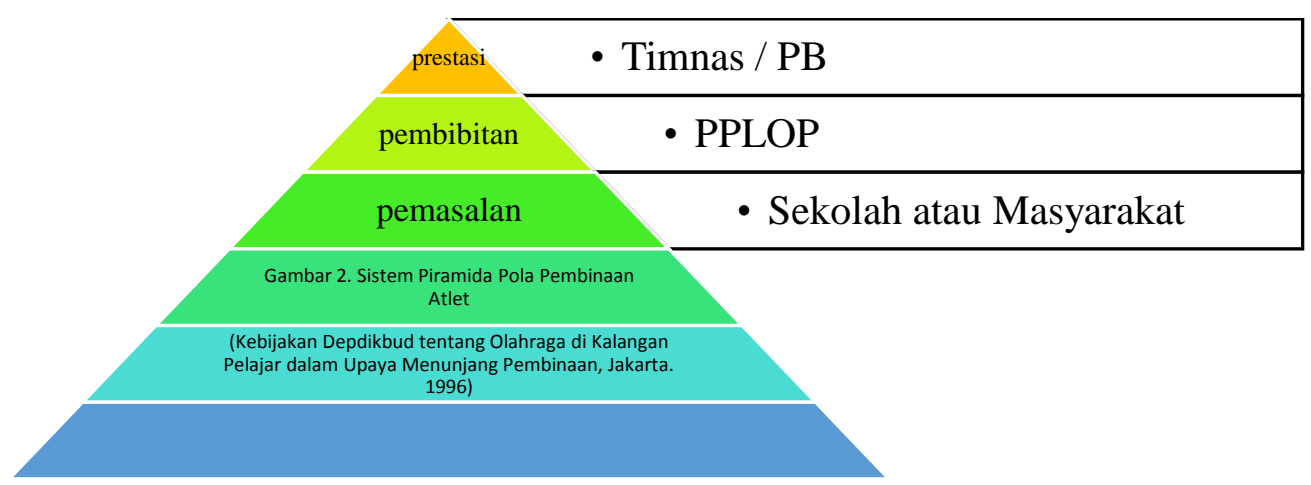

Gambar 3. Posisi PPLP dalam Pembinaan Olahraga 
Berdasarkan seluruh rangkaian penelitian dan data yang dikumpulkan dari berbagai sumber, peneliti menemukan beberapa data yang dapat mendukung temuan utama penelitian ini. Data ini diharapkan dapat menjawab kata-kata dari pertanyaan, atau dapat memberikan banyak informasi, berguna bagi siapa saja yang membutuhkannya. Berikut adalah hasil data yang diperoleh dari berbagai sumber informasi tentang panduan yang diterapkan PPLOP Jawa Tengah untuk kinerja yang optimal. Pembinaan tersebut antara lain; pembinaan latihan, pembinaan akademik, dan pembinaan agama.

\section{Pembinaan Latihan}

Pelaksanaan pembinaan latihan bagi atlet PPLOP Jawa tengah berdasarkan program latihan yang dibuat oleh pelatih secara kontinyu dan terarah. Program latihan dibuat dengan disesuaikan jadwal kegiatan atlet menghadapi kejuaraan yang diikuti. Pelatih melakukan usulan perencanaan program pelatihan sesuai dengan kebutuhan atlet, yang diajukan pada koordinator bidang pembinaan prestasi bekerjasama dengan stakeholder lain terkait seperti KONI dan Dinas Olahraga. Masing-masing pengelola melakukan koordinasi dan evaluasi dalam pembuatan perencanaan program latihan bagi atlet PPLOP Jawa Tengah.

Peran pelatih sangat penting dalam menjalankan dan mengontrol segala bentuk program latihan yang diberikan. Dalam menjalankan tugasnya pelatih juga dibantu oleh asisten pelatih. Program latihan yang diberikan pelatih banyak menekankan pada skill tiap anak serta pelatih selalu memperhatikan pengembangan fisik, perkembangan teknik dan juga perkembangan mental setiap anak dan setiap latihan pelatih selalu memberikan sesi game yang mengarah pada tujuan progam latihannnya. Pelatih selalu memberikan evaluasi seusai latihan guna memberitahukan kepada atlet apa yang telah dicapai maupun yang belum dicapai pada satu kali sesi latihan. Untuk mengatasi kejenuhan dalam melakukan setiap sesi latihan pelatih banyak menggunakan fariasi dan kombinasi dalam latihan.

Penentuan rencana latihan harus memperhatikan beberapa faktor yang mendukung keberhasilan latihan. Untuk mengembangkan rencana latihan yang baik, Anda harus memiliki semua tahapan rencana latihan: 1) rencana pelatihan jangka panjang, 2) rencana pelatihan jangka menengah, dan 3) rencana pelatihan jangka pendek. Selain itu, rencana latihan disusun dan disediakan sesuai dengan kebutuhan para atlet. Pelatih selalu mengevaluasi setiap latihan untuk menginformasikan para atlet tentang pencapaian dan tujuan yang belum tercapai selama pelatihan. Tujuan utama dari program latihan adalah untuk mengetahui kemampuan atlet dan mencapai prestasi yang terbaik.

Latihan dilaksanakan hari Senin hingga Jumat. Dalam sehari latihan dilaksanakan 2 kali yaitu, pagi jam 05.00 hingga pukul 07.00 WIB, dan sore jam 15.00 hingga pukul 17.00 WIB. Namun ketika atlet mengikuti kejuaraan latihan ditingkatkan namun repetisinya berkurang. Latihan yang dilakukan ketika mengikuti kejuaraan biasanya mematangkan teknik dan latihan visualisasi. Kendala dalam pelaksanaan program latihan terjadi ketika atlet mengalami cedera. Pembinaan atlet juga dilakukan di asrama, atlet dan pelatih haruslah mematuhi segala peraturan yang ada.

Pembinaan latihan meliputi; (1) Pembinaan fisik yang bertujuan untuk membentuk kondisi fisik atlet menjadivbaik. Ciri-ciri tersebut yaitu kekuatan, kecepatan, kelincahan, kelenturan, keseimbangan, daya tahan dan koordinasi gerak yang baik sesuai standar yang telah ditetapkan. Selain itu atlet-atlet dipersiapkan agar memiliki tubuh yang ideal antara tinggi dan berat badannya agar dapat mengembangkan kesegaran jasmaninya dengan baik. (2) Pembinaan teknik: bertujuan untuk menyiapkan atlet yang memiliki teknik tinggi guna memaksimalkan kemampuan dirinya. Pembinaan ini dimulai dengan mempelajari dan menguasai teknik dasar kemudian meningkat ke teknik sukar dan teknik tinggi. Bagi atlet yang mengalami kesulitan akan mengikuti latihan secara khusus untuk mempelajarinya sampai ia benar-benar menguasai teknik tersebut dengan baik. (3) Pembinan mental bertanding: bertujuan 
untuk membentuk mental juara dan tidak takut menghadapi siapa saja yang menjadi lawannya. Pembinaan ini dilakukan dengan cara melakukan simulasi tanding lawan temannya sendiri, mengadakan latih tanding.

Keberhasilan pencapaian atlet tidak jauh dari sumber yang saling terkait yang dapat mempengaruhi peningkatan pencapaian atlet (Indah, 2020; Saputra et al., 2021). Mirip dengan Dispora, KONI juga melaksanakan event kejuaraan Pekan Olahraga Provinsi yang dilaksanakan 4 tahun sekali. Jika di Koni atlet dan pelatih mereka menerima uang pelatihan setiap bulan selama setahun sebelum dimulainya pertandingan / kejuaraan. Pembinaan dilakukan guna mendapatkan hasil yang lebih maksimal terhadap para atlet pada saat pertandingan. Selain uang pembinaan para atlet juga diberi uang penghargaan bagi atlet dan pelatih yang berprestasi. Untuk mencapai hasil maksimal, mereka membutuhkan sarana prasarana sebagai tempat di mana atlet dan pelatih membuat latihan rutin agar kemampuan atlet dapat berhasil secara optimal. Dalam hal ini, Dinas Pemuda dan olahraga memiliki tiga belas fasilitas olahraga yang telah dimasukkan dalam penarikan biaya dan telah diatur dalam peraturan daerah, nomor 9, 2014 berkenaan dengan retribusi regional, sementara fasilitas olahraga yang tidak belum terkena retribusi ada enam fasilitas olahraga. Semua komponen ini akan sangat mendukung dalam keberhasilan peningkatan atlet, baik dari segi dana dan fasilitas olahraga dan infrastruktur.

Dalam penelitiannya, (Sirait \& Noer, 2021) sampai pada kesimpulan bahwa peningkatan prestasi atlet tidak terlepas dari kerjasama semua pihak yang terlibat, dalam hal ini Dinas Pemuda dan Olahraga, KONI, FORMI, atlet, pemasok dan pelatih. Pembina olahraga merupakan langkah awal dalam meningkatkan prestasi atlet. Menurut (Ortiz et al., 2015). Untuk mencapai prestasi atlet maka harus ada fasilitas sebagai wadah bagi atlet dan pelatih untuk melakukan prosedur latihan agar keterampilan atlet dapat mencapai hasil yang terbaik (Wandi et al., 2013). Dalam hal ini, 13 fasilitas olahraga Kementerian Pemuda dan Olahraga masuk dalam lingkup pemungutan retribusi dan pajak daerah diawasi dalam Perda Nomor 9 Tahun 2014, sedangkan enam fasilitas olahraga dikenakan pajak fasilitas olahraga. Semua komponen tersebut akan sangat membantu dalam menumbuhkembangkan keberhasilan atlet berprestasi baik dari segi pendanaan maupun sarana dan prasarana olahraga.

\section{Pembinaan Akademik}

Pembinaan akademik bekerja sama dengan Dinas Pendidikan Provinsi Jawa tengah. Atlet-atlet yang berada di PPLOP ada yang sekolah di sekolah umum (SMP dan SMA Negeri 11 semarang), ada juga yang home schooling. Untuk jam pelajaran bagi atlet PPLOP pencaksilat Jawa Tengah terjadi pengurangan, yaitu dimulai darim jam 08.00 hingga 13.30 WIB. Bagi aatlet yang sudah kelas 3 SMP dan kelas 3 SMA balai PPLOP menyediakan Guru les untuk mematangkan dalam mengahadapi Ujian Nasional. Hasil dari pembinaan akademik berpengaruh bagi keberadaa atlet PPLOP Jawa Tengah. Balai PPLOP Jawa Tengah sangat memperhatikan kemampuan akademis siswanya. Hal ini ditempuh dengan pembuatan jadwal wajib belajar setiap hari, dimana siswa harus dalam kondisi benar-benar belajar dan mendapatkan pantauan khusus dari pembina. Apabila mereka mendapat kesulitan, mereka menyampaikan permasalahan akademisnya kepada pembina. Dengan demikian pelatih dan Pembina dapat memantau proses belajar serta dapat menyelesaikan akademisnya dengan tepat.

Hubungan dengan pihak sekolah juga terus dibina agar semua informasi dari sekolah dapat digunakan sebagai pedoman pemantauan belajar siswa PPLOP. Setiap ada permasalahan di sekolah, guru sekolah dan Pembina serta pelatih PPLOP akan melakukan musyawarah untuk menyelesaikan masalah tersebut. Dengan demikian diharapkan siswa mampu mencapai nilai akademis sesuai dengan standar kompetensi dan KKM yang diharapkan. Akan tetapi seiring dengan banyaknya porsi latihan yang dijalani siswa PPLOP Jawa Tengah, mereka juga memiliki hambatan dalam prestasi akademik. Prestasi akademik para siswa PPLP Jawa Tengah 
di sekolah boleh dikatakan tidak terlalu menonjol. Meskipun nilai mereka sudah memenuhi standar KKM, tetapi nilai mereka umumnya tidak mampu meraih jajaran 10 besar di kelas. Hal tersebut dikarenakan faktor seperti ketatnya jadwal latihan dan bertanding atlet sehingga waktu belajar mereka menjadi terbatas; (2) faktor kelelahan fisik karena latihan dan jadwal pertandingan yang padat.

\section{Pembinaan Agama}

Keberhasilan seorang atlit dalam pencapaian prestos optimal tidak boleh melupakan kewajibannya kepada Tuhan Yang Maha Esa. Sebagai seorang yang beragama atlet dan pelatih dituntut untuk melaksanakan kewajiban beribadah dan belajar agama dengan sebaik- baiknya. Karena dengan bekal agama yang cukup akan membuat mental siswa terjaga dan akan memilih motivasi tinggi untuk meraih prestasi setinggi-tingginya. Oleh karena itu, pembinaan agama dan sikap tingkah laku perlu diberikan kepada siswa PPLP Pencak Silat Jawa Tengah dengan tujuan menjaga mental dan kebersihan diri dan hati.

\section{SIMPULAN}

Manajemen atlet PPLOP di Jawa Tengah dilaksanakan untuk mencapai hasil yang terbaik. Pembinaan dan pengembangan kinerja yang sistematis, hierarkis dan berkelanjutan. Model pengembangan kinerja yang diterapkan di PPLOP Jawa Tengah antara lain: pendidikan, pengembangan akademik dan pengembangan keagamaan. Proses peningkatan prestasi PPLOP Jateng sudah baik dan benar, terbukti dari prestasi para atlet di bidang olahraga, sains dan agama.

\section{DAFTAR PUSTAKA}

Adzalika, A. R., Soegiyanto, \& Rumini. (2019). Evaluasi Pembinaan Prestasi Atlet Cabang Olahraga Terukur (Atletik, Angkat Besi, Panahan dan Renang) Di Provinsi Lampung. Journal of Physical Education and Sport, 8(1), 56-61.

Alim, A. (2019). Hubungan Motivasi, Attitude, Anxiety Dan Self Efficacy Terhadap Prestasi Atlet Tenis Lapangan Level Junior Dan Senior. Medikora, 17(2), 83-90. https://doi.org/10.21831/medikora.v17i2.29179

Allung, J. R., Soegiyanto, \& Kusuma, D. W. Y. (2019). Evaluating Coaching Achievement Taekwondo Sports Branch of Students Development Center and Sport Training NTT. Journal of Physical Education and Sports, 8(2), 116-120.

Ary, D., Jacobs, L. C., Sorensen, C., \& Razavieh, A. (2009). Introduction to Research in Education (8th ed.).

Damayanti, E. S. (2019). Evaluasi Program Pembinaan Cabang Olahraga Karate SATLAK PRIMA Tahun 2017. Penjaskesrek, 6(1), 11-20.

Danardani, W. (2015). Interaksi Pelatih Dan Atlet Dalampenetapan Tujuan. Medikora, IV(2), 35-49. https://doi.org/10.21831/medikora.v0i2.4814

DINPORAPAR. (2018). Buku Pedoman Penyelenggaraan Pemusatan Pendidikan dan Latihan Olahraga Pelajar (PPLOP) Provinsi Jawa Tengah. Dinas Kepemudaan Olahraga dan Pariwisata Jawa Tengah.

Hadiyanto, W., \& Khamidi, A. (2021). Manajemen Pembinaan Persatuan Atletik Seluruh Indonesia Kabupaten Sampang. Jurnal Prestasi Olahraga, 4(6), 141-148. 
Haryadi, W. M., Pratidina, G., \& Seran, M. Y. (2017). Studi Manajemen Pembinaan Olahraga Sepak Bola Di Klub Persatuan Sepak Bola Kota Bogor Oleh Kantor Pemuda Dan Olahraga Kota Bogor. Jurnal Governansi, 2(1), 45-50. https://doi.org/10.30997/jgs.v2i1.208

Hidayat, R., Febriani, A. R., Budi, D. R., \& Listiandi, A. D. (2019). Pembinaan Prestasi Tim Sepak Takraw Putri Jawa Tengah Menuju PON XVIII Tahun 2012 di Riau. Jendela Olahraga, 4(2), 37. https://doi.org/10.26877/jo.v4i2.3815

Iklil, M., \& Khamidi, A. (2021). MANAJEMEN PEMBINAAN BOLA TANGAN KLUB GIRI GRESIK Muhammad Iklil*, Dr. Amrozi Khamidi, S.Pd., M.Pd. Jurnal Prestasi Olahraga, $4(8), 56-62$.

Indah, E. P. (2020). Evaluasi Penyelenggaraan Program Pusat Pendidikan Dan Latihan Olahraga Pelajar Loncat Indah Provinsi Kalimantan Selatan. Multilateral Jurnal Pendidikan Jasmani Dan Olahraga, 19(1), 58-66. https://doi.org/10.20527/multilateral.v19i1.8462

Indonesia, P. R. (2005). Undang-Undang Sistem Keolahragaan Nasional Nomor 3 Tahun 2005.

Kristiyanto, A. (2016). Seikat Opini Usilku Keolahragaan Dalam Esai. CV. KEKATA GROUP.

Nasrulloh, A., Sumaryanto, Sumarjo, \& Nugroho, S. (2020). The Analysis of Management Function of Sport Hall (GOR) Yogyakarta State University. https://doi.org/10.5220/0009785202960302

Nasrulloh, A., Sumaryanto, Sumarjo, Nugroho, S., \& Antoni, M. S. (2021). Does the Implementation of the Management Function Have an Impact on Service Quality? A Study at the HSC Fitness Center. International Journal of Human Movement and Sports Sciences, 9(5), 1019-1028. https://doi.org/10.13189/SAJ.2021.090524

Nicolas, M., Gaudreau, P., \& Franche, V. (2011). Perception of coaching behaviors, coping, and achievement in a sport competition. Journal of Sport and Exercise Psychology, 33(3), 460468. https://doi.org/10.1123/jsep.33.3.460

Ortiz, J. I., Rodriguez, A. C., \& Minguet, J. L. C. (2015). Sports Management, Leadership in the Organization. Journal of Physical Education and Sports Management, 2(2), 56-65. https://doi.org/10.15640/jpesm.v2n2a5

Pambudi, D. K. (2020). Analisis Standarisasi Fasilitas Gedung Olahraga Universitas Negeri Yogyakarta. Medikora, 19(1), 46-52. https://doi.org/10.21831/medikora.v19i1.30887

Prasetyo, Y. (2015). Kesadaran Masyarakat Berolahraga Untuk Peningkatan Kesehatan Dan Pembangunan Nasional. Medikora, 11(2), 219-228. https://doi.org/10.21831/medikora.v11i2.2819

Putra, A. Y. (2018). Analisis pelaksanaan manajemen Pemusatan Pendidikan dan Latihan Olahraga Pelajar (PPLOP) sepak takraw Jawa Tengah tahun 2017. Journal Power Of Sports, 1(1), 29. https://doi.org/10.25273/jpos.v1i1.1863

Saputra, B., Armariena, D. N., \& Iswana, B. (2021). Survei Pembinaan Prestasi Olahraga 
Sepakbola Atlet. Jambura Journal of Sports Coaching, 3(1), 12-22.

Sirait, J., \& Noer, K. U. (2021). Implementasi kebijakan keolahragaan dan peran pemangku kepentingan dalam peningkatan prestasi atlet The implementation of sports policies and the role of stakeholders in improving athlete achievement. JORPRES (Jurnal Olahraga Prestasi), 17(1), 1-10.

Sugiyono. (2015). Metode Penelitian dan Pengembangan (Research and Development) (Sofia Yustiyani Suryandari (Ed.)). Alfabeta.

Wandi, S., Nurharsono, T., \& Raharjo, A. (2013). Pembinaan Prestasi Ekstrakurikuler Olahraga Di Sma Karangturi Kota Semarang. Active - Journal of Physical Education, Sport, Health and Recreation, 2(8), 524-535. https://doi.org/10.15294/active.v2i8.1792

Wijayanti, D. G. S., Soegiyanto, \& Nasuka. (2016). Pembinaan Olahraga untuk Penyandang Disabilitas di National Paralympic Committee Salatiga. Journal of Physical Education and Sport, 5(1), 17-23.

Yahya, \& Irfandi. (2020). Pelaksanaan Manajemen Pemusatan Pendidikan Dan Latihan Olahraga Bagi Pusat Pembinaan Latihan Mahasiswa (PPLM) Cabang Olahraga Karate Kota Banda Aceh. 8(2), 71-81.

Yulisatria, G., Juntara, P. E., \& Ramadhani, A. (2021). Evaluasi Pembinaan Prestasi Judo Kota Bandar Lampung. 03(02), 168-177.

Yuniana, R., \& Nasrulloh, A. (2019). Tingkat Kepuasan Members terhadap Strategi Pemasaran di Lembah Fitness Centre Universitas Gajah Mada. MEDIKORA, 18(1). https://doi.org/10.21831/medikora.v18i1.29195. 